\title{
A medida acautelatória de indisponibilidade de bens particulares dos sócios, administradores e conselheiros na sociedade anônima aberta
}

\author{
The precautionary measure for the unavailability of the assets of the controlling \\ shareholders, directors and advisers of the Publicly-Held Company
}

\author{
JORGE LUIZ LOPES DO CANTOa
}

\begin{abstract}
RESUMO
O presente estudo visa perscrutar os pressupostos processuais para concessão da cautela preparatória de indisponibilidade de bens particulares dos sócios controladores, administradores e dos conselheiros de sociedade anônima aberta, bem como os efeitos jurídicos daí decorrentes, à luz da doutrina e jurisprudência.

Palavras-chave: Cautelar Preparatória. Indisponibilidade de bens. Sociedade Anônima. Capital Aberto. Sócios. Controlador. Administrador. Conselheiro.
\end{abstract}

\begin{abstract}
This research aims to examine the procedural prerequisites for granting the preparatory precautionary measure of the unavailability of the assets of the controlling shareholders, directors and advisers of the Publicly-Held Company, as well as the legal consequences arising therefrom, within the doctrine and jurisprudence spectrum. Keywords: Preparatory Precautionary Measure. Unavailability of Assets. Joint-Stock Company. Publicly-Held Company. Shareholders. Controlling Shareholder. Director. Advisers.
\end{abstract}

\section{INTRODUÇÃO}

O presente estudo se trata de breve escorço sobre a repercussão jurídica da indisponibilidade de bens no patrimônio particular daquelas pessoas que detêm, em algum grau, a responsabilidade de gerir, bem administrar e fiscalizar uma sociedade anônima de capital aberto.

A sociedade anônima de capital aberto é um ícone do sistema capitalista, no sentido que se trata da personificação de direitos, interesses jurídicos e patrimônio autônomo distinto da personalidade daqueles que, individualmente, tem poder decisório de administrar a mesma, em prol da concretização de seu objeto estatutário.

A medida processual preparatória visa garantir a solvabilidade de determinadas pessoas que atuam na sociedade anônima de capital aberto, a fim de possibilitar eventual responsabilidade pessoal destas. Por sua vez, a responsabilização pessoal desses atores da companhia aberta tem por finalidade assegurar aos demais sócios e a terceiros a obtenção de eventual ressarcimento decorrente da má fé e culpa lato sensu (dolo e culpa).

O estudo precitado começou a ser desenvolvido nos idos de 1996, quando da discussão e elaboração da atual lei de falência e recuperação de empresas, passando a existir regulação específica a esse respeito por ocasião da edição deste diploma (art. $83, \S 2^{\circ}$, da Lei no 11.101/2005). Entretanto, o primeiro texto legal que regulamenta de forma expressa esta possibilidade jurídica no país é o fiscal, mediante o art. $4^{\mathrm{o}}, \S 1^{\mathrm{o}}$, da Lei $\mathrm{n}^{-} 8.397 / 92$, de acordo com a redação dada pela Lei $\mathrm{n}^{\mathrm{o}}$ 9.532/97.

a Desembargador do TJRS. E-mail: <jcanto@tj.rs.gov.br>. 
Cabe mencionar que na década de 90 já havia decisões na seara falimentar a esse respeito, com base no poder geral de cautela do juiz da falência (art. 14, VI, da Lei no 7.661/45, atual 99, inc. VII, da Lei no $11.101 / 2005)$.

O primeiro ponto a ser abordado no presente trabalho diz respeito à sociedade anônima de capital aberto, esta, em apertada síntese, é aquela que admite a captação de recursos mediante negociação de ações no mercado mobiliário, ou seja, bolsa de valores ou mercado de balcão.

Sob esse viés é que há o interesse jurídico de proteger acionistas e terceiros, no caso, aplicadores no mercado de ações, como os debenturistas, quanto à malversação dos recursos de companhia aberta, resultante do controle exercido, da má administração ou da conivência com esta.

Por fim, o último tópico a ser tratado no presente trabalho é quanto às questões de ordem processual, que exsurgem da cautela de indisponibilidade de bens, no que tange aos seus efeitos em função de sua natureza jurídica e requisitos necessários para concessão da mesma, além do prazo razoável pela qual esta pode vigorar.

Desta forma, a complexidade deste tema, diante da interpolação de questões de direito material e processual, privado e público, bem como garantias de ordem constitucional, assim como, a prevalência entre interesses distintos, no caso o particular e o coletivo, é que torna fascinante este estudo, diante dos mais diversos matizes jurídicos a serem examinados.

\section{SOCIEDADE ANÔNIMA DE CAPITAL ABERTO}

A companhia aberta é a que melhor personifica o sistema capitalista, pois se trata de sociedade de capital, cuja formação gira em torno da obtenção de recursos no mercado para constituição desta, a fim de alcançar a justa remuneração do investimento feito mediante a realização do objeto social, sendo mais evidente aqui o intuito de obter o lucro almejado, sob o ponto de vista econômico.

O insigne jurista Modesto Carvalhosa ${ }^{1}$, a meu ver, é quem melhor define este tipo de sociedade, ao lecionar que:

Quando, por outro lado, a companhia procura recursos de capital próprio (ações) ou de terceiros (debêntures) junto ao público, oferecendo a qualquer pessoa desconhecida ações e debêntures de sua emissão, temos uma companhia aberta.
Neste caso, em face da dispersão dos tomadores de valores mobiliários emitidos pela companhia, que se presume incapazes de formar uma comunidade apta a defender eficazmente seus interesses perante aquela, seus controladores e administradores, a lei estabelece um regime especial de tutela do Poder Público em favor dessa coletividade de acionistas, debenturistas e demais portadores de títulos acionários.

Se a sociedade logra ou não colocar seus títulos em consequência da oferta, pouco importa. Basta que haja a oferta junto ao público investidor para que, sobre a sociedade, incida o regime especial de tutela estatal previsto em lei.

Não obstante isso, resta indubitável no art. $4^{\circ}$ da Lei das Sociedades Anônimas que há intervenção do Estado na regulação deste mercado, diante da previsão de que a empresa deve registrar-se na Comissão de Valores Mobiliários para negociar suas ações na Bolsa de Valores. Destaque-se que o prévio registro mostrase essencial quando a sociedade anônima de capital aberto é de economia mista, uma vez que o prevalente interesse público se faz presente.

Em qualquer destas hipóteses há que se levar em conta o interesse do particular, na condição de investidor, e o interesse público, no sentido de preservar a coletividade que atua na economia para consecução de um fim determinado, ao mesmo tempo que busca o desenvolvimento desta e o avanço econômico-social daí decorrente.

Desse modo, imprescindível voltar a atenção para este tipo de sociedade de capital, sem olvidar-se daqueles que a controlam, gerem ou administram, bem como as pessoas que atuam em seus conselhos de administração ou fiscal, as quais podem ser consideradas, no mínimo, coniventes com a má administração deste tipo de sociedade em prejuízo da coletividade.

\subsection{Os sócios, administradores e conselheiros da companhia aberta}

A responsabilidade dos sócios, administradores e conselheiros na sociedade anônima aberta não decorre de causa indistinta ou de razão jurídica que não esteja subsumida na forma de participação nesta, pelo contrário, estão sujeitos à indisponibilidade de bens apenas aqueles atores que atuarem na gestão ou administração da referida companhia, ou ainda, que forem coniventes com os atos praticados por estes, como na hipótese dos conselheiros fiscais.

Igualmente, há que se sopesar a prática de conduta ilícita e o nexo causal entre esta e o dano ocasionado, para que surja o dever de reparação, aqui independe 
se é adotada a teoria da responsabilidade subjetiva ou objetiva, pois, sob o ponto de vista que se analisar, há necessidade de averiguar se houve a prática de ilicitude, de má-gestão ou de atos contrários ao estatuto social.

Portanto, a medida acautelatória de indisponibilidade de bens particulares do sócio, administrador ou mesmo conselheiro decorre do exame prévio da responsabilidade destes pela prática dos atos precitados, que importem em prejuízo da companhia aberta considerada, dos sócios desta, ou de terceiro que investiu ou negociou com aquela.

\section{a) Extensão de cautela inerente à patrimônio distinto daquele pertencente à sociedade anônima de capital aberto}

A extensão dessa cautela preparatória de indisponibilidade de bens visa garantir a solvabilidade de sócio controlador, gestor, administrador ou de conselheiro da referida sociedade, que tenha o dever de responder pelos atos praticados e ressarcir os prejuízos causados, enquanto presentante ou representante daquela, em função de ter se beneficiado economicamente dos mesmos, direta ou indiretamente.

A responsabilização do patrimônio pessoal dos sócios controladores, administradores, gestores ou conselheiros de uma sociedade anônima aberta é exceção, pois se trata aqui de patrimônios distintos e autônomos, cada qual respondendo, como regra, pelas obrigações que assumem em suas relações jurídicas. Assim, a responsabilidade pessoal em questão recai sobre o patrimônio pertencente à determinada pessoa, seja ela natural ou jurídica, que pratique os atos ou negócios jurídicos que causem lesão à sociedade, aos sócios ou a terceiro, cujo nexo causal deve estar perfeitamente delineado.

Desse modo, é possível a ampliação da medida processual de indisponibilidade dos bens ao patrimônio de pessoa diversa da sociedade anônima em questão, de sorte a bloquear este e permitir, durante lapso de tempo certo, o exame dos atos e negócios jurídicos que teriam ocasionado danos à companhia em questão ou a terceiros, que mantiveram relação jurídica com esta, a fim de permitir a justa reparação dos prejuízos causados.

\section{b) As pessoas passíveis de atingimento pela cautela de indisponibilidade de bens - Sujeito Passivo}

Ressalte-se que as pessoas que se sujeitam a este tipo de cautela preparatória são exclusivamente os sócios, administradores, gestores e conselheiros que detêm poder de gestão, administração e fiscalização sobre os atos e negócios jurídicos da sociedade anônima aberta.

A partir de tal premissa, conclui-se que não se sujeita ao bloqueio de seu patrimônio o mero sócio capitalista que não disponha dos poderes precitados, estando restrita a sua participação ao capital investido e a perceber os frutos civis daí decorrentes.

Igualmente, também não se submete a este tipo de medida o conselheiro que não participa relações jurídicas precitadas, ou cuja aprovação destas esteja em consonância com a ordem jurídica vigente, inexistindo omissão que caracterize culpa e possa importar em responsabilidade civil.

Estabelecidos estes parâmetros, resta claro que o denominado sócio controlador, assim como seus presentantes ou representantes, estão sujeitos à cautela de indisponibilidade de seus bens particulares, sendo necessário para tanto investigar se houve locupletamento ilícito em virtude de seu poder de mando na realização de determinado ato ou negócio jurídico, o qual resulte em prejuízo da sociedade controlada, da coletividade que participa (acionista, etc.) ou mantém relação negocial com aquela.

O culto doutrinador Comparato $^{2}$ traça com precisão o perfil de quem é o controlador numa sociedade anônima, como se vê a seguir:

$\mathrm{Na}$ economia da nova sociedade anônima o controlador se afirma como seu mais recente órgão, ou se preferir a explicação funcional do mecanismo societário, como o titular de um novo cargo social. Cargo, em sua mais vasta acepção jurídica, designa um centro de competência, envolvendo uma ou mais funções. $\mathrm{O}$ reconhecimento de um cargo, em qualquer tipo de organização, faz-se pela definição de funções próprias e necessárias. Ora, tais funções existem vinculadas à pessoa do controlador. No vigente direito acionário brasileiro, elas podem resumir-se no poder de orientar e dirigir, em última instância, as atividades sociais; ou como se diz no art. 116, alínea "b" da Lei no 6.404, no poder de "dirigir as atividades sociais e orientar o funcionamento dos demais órgãos da companhia" (com o reconhecimento implícito de que o acionista controlador é um dos órgãos da companhia). Trata-se de um feixe de funções indispensáveis ao funcionamento de qualquer entidade coletiva como assinalamos anteriormente - e especialmente da sociedade anônima. Poderia, sem dúvida, o legislador manter essas prerrogativas diluídas no corpo acionário, tal como ocorria no passado. Preferiu, no entanto, desde a Lei n. 6.404, localizálas no "titular de direitos de sócio que lhe assegurem, de modo permanente, a maioria dos votos nas deliberações da assembleia geral e o poder de eleger a maioria dos administradores da companhia". 
Igualmente, os sócios administradores ou gestores da companhia aberta, assim como aqueles designados para administrá-la ou geri-la, se sujeitam à medida acautelatória em questão, a fim de aferir a prática de ato ou negócio lesivo aos interesses da mesma, quer em razão da ilicitude da conduta adotada, quer em função de ser o ato praticado contrário à lei ou aos estatutos daquela. Em qualquer destas hipóteses responderiam os sócios controladores, administradores ou gestores da companhia aberta com o patrimônio particular.

Note-se que a responsabilidade aqui é solidária e ilimitada, conforme conclusão do enunciado $\mathrm{n}^{\mathrm{O}} 59$ do CEJ - CJF, devendo os sócios controladores, administradores ou gestores reparar a integralidade do prejuízo ocasionado à referida sociedade, aos sócios desta e a terceiros, em função dos atos ou negócios jurídicos realizados da forma preconizada anteriormente.

Há que se distinguir aqui duas espécies de conselheiros: a) os que integram o denominado conselho de administração; e b) os que compõem o conselho fiscal da companhia aberta.

$\mathrm{Na}$ primeira hipótese os conselheiros respondem também pelo excesso, tanto de poder, como por ultrapassar o objeto social, além das circunstâncias elencadas anteriormente.

Já no que diz respeito ao conselheiro fiscal o patrimônio particular deste estará sujeito a eventual medida de indisponibilidade, caso tenha se omitido, ainda que por culpa strictu sensu (negligência, imprudência e imperícia), de se manifestar específica e circunstanciadamente sobre a ocorrência de algum dos atos ou negócios jurídicos passíveis de gerar a responsabilização dos administradores ou gestores da sociedade em tela, sendo ou não, neste caso, detentores da condição de sócio.

Aqui há que se ter em mente a denominada omissão prejudicial, que sonega o direito de informação dos demais acionistas ou investidores a dado sigiloso ou reservado que seria decisivo para prática de determinado ato ou negócio, ou que causaria dano à companhia em função de retirar desta determinada oportunidade de negócio que lhe seria vantajosa.

Conclui-se que a medida cautelar em análise inerente às pessoas anteriormente elencadas decorre do direito subjetivo de reparação dos danos que deram causa, em decorrência da própria Lei especial das Sociedades Anônimas (art. 158) ou das regras gerais dispostas no estatuto civil.

\subsection{Efeitos sobre os bens particulares daqueles que atuam na gestão, administração e fiscalização da sociedade anônima aberta}

É oportuno destacar que para surtirem efeitos sobre os bens particulares dos sócios controladores, administradores e conselheiros, como analisado anteriormente, a eficácia pretendida e a medida preparatória em questão decorrem de justa causa e estão, necessariamente, vinculadas a ato ou a negócio jurídico certo, bem como possuem caráter excepcional, pois o bom direito alegado na cautela proposta deve estabelecer o nexo causal entre aquela e o resultado descrito, isto é, o prejuízo econômico determinado ou determinável.

Ainda, é preciso delimitar qual o patrimônio será atingido, que parcela deste é economicamente útil para reparar o prejuízo ocasionado e o lapso temporal que os bens submetidos a esta medida de indisponibilidade deverá ser considerado para tanto, ou seja, o prazo no qual ficarão adstritos à averiguação da responsabilidade dos sócios controladores, administradores e conselheiros.

\section{a) Impossibilidade temporária de transmissão dos bens pertencentes ao sócio controlador, administradores e conselheiros da companhia}

O primeiro ponto a ser abordado neste tópico diz respeito à duração dos efeitos da medida acautelatória sobre os bens particulares das pessoas antes referidas. À toda evidência, este interregno de tempo não é indefinido, ao contrário, está sujeito a termo final.

A questão a ser definida é qual é este prazo? A resposta a esse questionamento parece óbvia. A medida cautelar preparatória em questão deve perdurar até ser solvida a ação principal indicada nesta, que visa apurar a responsabilidade dos sócios, dos administradores ou dos conselheiros.

A razão da referida limitação temporal decorre do fato de que na hipótese de ser comprovada a responsabilidade de reparar o prejuízo causado por parte do sócio controlador, administrador ou conselheiro, estar-se-ia diante do fumus boni juris alegado na cautelar de indisponibilidade de bens daqueles, bem como do periculum in mora de não ser adotada esta medida de urgência, pois haveria o risco deles se desfazerem de seu patrimônio e se reduzirem a insolvabilidade.

Contudo, encerrado o prazo para apurar a referida responsabilidade, desaparece a possibilidade jurídica de obter o ressarcimento do prejuízo causado, quer em função da prescrição ou da decadência, quer resultando da inexistência do dever de reparar o dano ocasionado por parte daqueles, conclusão que se deduz, em função da improcedência da ação principal ajuizada, que tinha por escopo alcançar a responsabilização das pessoas supracitadas sujeitas à medida acautelatória em tela.

Assim, a referida medida cautelar vigora por prazo certo, ou seja, até a apuração da responsabilidade 
daqueles que respondem com o patrimônio particular pelo prejuízo ocasionado à sociedade anônima de capital aberto, aos sócios destas e mesmo a terceiros, que mantêm relação jurídica com a referida companhia.

\section{b) Direito de uso, gozo e fruição dos proprietários na vigência da medida cautelar de indisponibilidade}

É de se destacar que a indisponibilidade de bens alcança apenas uma das faculdades do domínio e, ainda, de forma parcial, pois o proprietário do bem atingido pela medida em questão tem restringido o seu direito de transmitir para outrem o domínio sobre a coisa, corpórea ou incorpórea (bens ou direitos), sujeita a cautela analisada.

Desse modo, é atingido parte do direito de disposição, permanecendo o proprietário, sujeito a esta medida cautelar, com a posse da coisa, uso, gozo, fruição e o direito reipersecutório atinente ao bem indisponível, podendo adotar todas as medidas necessárias à conservação do mesmo, bem como perceber os frutos relativos a este, o que cessará mediante a excussão da coisa (corpórea ou incorpórea) através de ação própria.

Portanto, trata-se a indisponibilidade de bens de medida cautelar temporária de restrição de uma das faculdades do domínio, no caso, o direito de dispor livremente daquele patrimônio, até que seja apurada a responsabilidade dos atores precitados pelos prejuízos que deram causa.

\section{A CAUTELA DE INDISPONIBILIDADE DE BENS}

A cautela de indisponibilidade de bens é preparatória, ou seja, trata-se de medida acessória, desprovida de caráter satisfativo, não prescindindo da indicação da demanda principal a ser dirimida, bem como se destina a garantir a solvabilidade do sócio controlador, administrador, gestor ou conselheiro de sociedade anônima de capital aberto, a fim de que seja apurada a responsabilidade daqueles pelos prejuízos que deram causa à sociedade, aos demais sócios desta ou a terceiros.

A incidência daquela medida ocorre sobre a faculdade de disposição do domínio de determinada coisa, de acordo com o esclarecido anteriormente, bem como vigora temporariamente até ser solvida a ação principal que visa à indenização dos prejuízos causados pelas pessoas supracitadas, as quais respondem com o seu patrimônio particular.

\subsection{A tutela de indisponibilidade de bens do sócio controlador, administradores e conselheiros da sociedade anônima aberta}

O bom direito alegado decorre da possibilidade jurídica de existir o dever de reparar ou de pagar dívida exequível por parte do sócio controlador, administrador e conselheiro pela prática de conduta ilícita, consubstanciada em abuso de poder, ato ou negócio contrário à ordem jurídica ou aos estatutos da empresa.

Ao passo que o perigo da demora na prestação jurisdicional está adstrito ao risco de insolvabilidade do proprietário dos bens precitados, o que inviabilizaria eventual excussão destes para satisfazer o débito decorrente da ação principal declinada na mesma.

É de se elucidar que tal cautela também pode ser incidental, o que seria possível em dois tipos de execução: a) a coletiva falimentar; e b) a fiscal. A primeira, ocorrerá na falência como medida preparatória para apurar a responsabilidade do sócio controlador ou administrador pela quebra, isto é, se esta decorreu da malversação do patrimônio da empresa. Já a segunda, dar-se-á no executivo fiscal com o fim de garantir o proveito econômico pretendido, coibindo o dolo, a fraude ou a má fé daquele tipo de ator da sociedade anônima de capital aberto.

Note-se que a tutela cautelar em questão destinase a efetividade da prestação jurisdicional, na medida em que objetiva manter incólume o patrimônio do devedor, a fim de que os credores exerçam o seu direito de reparação mediante a liquidação judicial deste.

\section{a) Hipóteses de incidência e solução jurisprudencial}

$\mathrm{O}$ direito pátrio estabelece expressamente a indisponibilidade de bens, tanto no art. $4^{\circ}, \S 1^{\circ}$, da Lei n. 8.397/92, como no art. 83, § 2º da Lei n. 11.101/2005, regulando as condições para obtenção da referida cautela acessória.

Inicialmente, passa-se a abordar a matéria que diz respeito a indisponibilidade de bens decorrente de medida cautelar que precede o executivo fiscal, cuja aparência de bom direito - fumus boni juris - está consubstanciada na existência de obrigação líquida e exigível, bem como na possibilidade jurídica de existir a prática de determinada conduta ilícita por parte do sócio controlador, administrador ou conselheiro que implique no dever de reparação a pessoa certa, física ou jurídica.

O segundo requisito a ser examinado para concessão da referida cautela preventiva é o risco de dano grave ou de difícil reparação - periculum in mora -. Aqui há 
que se ater à possibilidade daquelas pessoas, em face das quais se busca a reparação, estarem em situação de déficit econômico. Note-se que neste caso deve se atentar a duas circunstâncias fáticas específicas: a primeira, a identificação do prejuízo no que concerne a sua extensão; a segunda, a proporção suficiente do patrimônio particular do sócio controlador, do administrador e conselheiro da companhia aberta que seja útil à reparação pretendida.

A proporcionalidade aqui é essencial, pois se de um lado o bloqueio autorizado não pode impedir o prosseguimento da atividade mercantil de determinada sociedade, de outro, quando incidir sobre coisa atinente ao patrimônio de pessoa natural, não deve reduzir esta ao estado de miserabilidade, atentando a dignidade da pessoa humana, ou a impeça de prosseguir em suas atividades profissionais habituais.

A esse respeito é oportuno trazer à baila as lições do jurista Humberto Theodoro $\mathrm{Jr}^{3}{ }^{3}$ que seguem:

É fácil verificar, portanto, que a proibição de dispor, regulada pela Lei $8.937 / 92$, não é automática, nem muito menos pode ser imposta discricionariamente pelo juiz. Tal como fez o Código de Processo Civil (LGL/1973/5), em relação ao arresto, a lei especial também sujeitou a medida cautelar fiscal a requisitos que obrigatoriamente devem ser demonstrados pela parte promovente e que, dentro da técnica geral, da tutela cautelar, correspondem ao fumus boni iuris e ao periculum in mora: o primeiro localiza-se na comprovação de existência de obrigação líquida e certa, documentalmente revelada (caput do art. 2o) e o segundo situa-se na conduta do devedor inadimplente que põe em risco a exeqüibilidade do crédito fazendário, diante do fundado receio de que irá fazer desaparecer os bens que, a seu tempo, deverão suportar a penhora no processo de execução fiscal (incs. I a V do art. $2^{\circ}$ ).

É sempre bom lembrar a insuperável lição de Calamandrei de que todos provimentos jurisdicionais existem como "instrumento do direito material, que por intermédio deles atua". Nos provimentos cautelares, porém, "verifica-se uma instrumentalidade qualificada, ou seja, elevada, por assim dizer, ao quadrado: eles são, de fato, inquestionavelmente, um meio predisposto para a melhor eficácia do provimento definitivo, que a sua vez é um meio para a atuação do direito; isto é, são eles, em relação à finalidade última da função jurisdicional, instrumento do instrumento". Vale dizer: os provimentos cautelares nunca são um fim em si mesmos, e surgem sempre "da existência de um perigo de dano jurídico, derivado do atraso de um provimento jurisdicional definitivo (periculum in mora)" (apud Clayton Maranhão, in Rev. Direito Processual-Genesis, Curitiba, 1996, v. I, p. 134).
Nesse diapasão é entendimento jurisprudencial do Superior Tribunal de Justiça ${ }^{4}$, cujo precedente delimita o uso da referida cautela preventiva, que colaciono a seguir:

PROCESSUAL TRIBUTÁRIO. MEDIDA CAUTELAR FISCAL. INDISPONIBILIDADE DOS BENS DOS SÓCIOS INTEGRANTES DO CONSELHO DE ADMINISTRAÇÃO. LEI 8.397/92. RESPONSABILIDADE TRIBUTÁRIA. AUSÊNCIA DE COMPROVAÇÃO DE EXCESSO DE MANDATO, INFRAÇÃO À LEI OU AO REGULAMENTO.

1. É assente na Corte que o redirecionamento da execução fiscal, e seus consectários legais, para o sócio-gerente da empresa, somente é cabível quando reste demonstrado que este agiu com excesso de poderes, infração à lei ou contra o estatuto, ou na hipótese de dissolução irregular da empresa (Precedentes: REsp no 513.912/MG, Rel. Min. Peçanha Martins, DJ de 01/08/2005; REsp no 704.502/RS, Rel. Min. José Delgado, DJ de 02/05/2005; EREsp no 422.732/RS, Rel. Min. João Otávio de Noronha, DJ de 09/05/2005; e AgRg nos EREsp no 471.107/MG, deste relator, DJ de 25/10/2004).

2. Os requisitos necessários para a imputação da responsabilidade patrimonial secundária na ação principal de execução são também exigidos na ação cautelar fiscal, posto acessória por natureza.

3. Medida cautelar fiscal que decretou a indisponibilidade de bens dos sócios integrantes do Conselho de Administração da empresa devedora, com base no artigo 4을 da Lei 8.397/92.

4. Deveras, a aludida regra deve ser interpretada cum grano salis, em virtude da remansosa jurisprudência do STJ acerca da responsabilidade tributária dos sócios.

5. Consectariamente, a indisponibilidade patrimonial, efeito imediato da decretação da medida cautelar fiscal, somente pode ser estendida aos bens do acionista controlador e aos dos que em razão do contrato social ou estatuto tenham poderes para fazer a empresa cumprir suas obrigações fiscais, desde que demonstrado que as obrigações tributárias resultaram de atos praticados com excesso de poderes ou infração de lei, contrato social ou estatutos (responsabilidade pessoal), nos termos do artigo 135, do CTN. No caso de liquidação de sociedade de pessoas, os sócios são “solidariamente" responsáveis (artigo 134, do CTN) nos atos em que intervieram ou pelas omissões que lhes forem atribuídas.

6. Precedente da Corte no sentido de que: “(...) Não deve prevalecer, portanto, o disposto no artigo $4^{\circ}$, § $2^{\circ}$, da Lei 8.397/92, ao estabelecer que, na concessão de medida cautelar fiscal, 'a 
indisponibilidade patrimonial poderá ser estendida em relação aos bens adquiridos a qualquer título do requerido ou daqueles que estejam ou tenham estado na função de administrador'.

Em se tratando de responsabilidade subjetiva, é mister que lhe seja imputada a autoria do ato ilegal, o que se mostra inviável quando o sócio sequer era administrador da sociedade à época da ocorrência do fato gerador do débito tributário pendente de pagamento. (...)" (REsp 197278/AL, Relator Ministro Franciulli Netto, Segunda Turma, DJ de 24.06.2002)

7. In casu, verifica-se que a decretação da indisponibilidade dos bens dos sócios baseou-se, tão-somente, no fato de integrarem o Conselho de Administração da Olvepar S.A. - Indústria e Comércio, "com competência para fiscalizar a gestão dos diretores, através de exame de livros e documentos da sociedade, bem como, para solicitar informações sobre contratos celebrados, incluindo-se o presente Contrato de Benefício Fiscal concedido à referida empresa por intermédio do PRODEI (Programa de Desenvolvimento Industrial do Estado)", o que configura ofensa ao artigo 135, do CTN.

8. Ressalva do ponto de vista no sentido de que a ciência por parte do sócio-gerente do inadimplemento dos tributos e contribuições, mercê do recolhimento de lucros e pro labore, caracteriza, inequivocamente, ato ilícito, porquanto há conhecimento da lesão ao erário público.

9. Recursos especiais providos. (REsp 722.998/ MT, Rel. Ministro LUIZ FUX, PRIMEIRA TURMA, julgado em 11/04/2006, DJ 28/04/2006, p. 272)

Por fim, há que se examinar a cautela preventiva de indisponibilidade de bens particulares dos sócios controladores, administradores e conselheiros da companhia aberta na execução coletiva falimentar, cuja aparência de bom direito - fumus boni juris - decorre do exame de eventual abuso de direito ou da infração à lei ou ao estatuto social por parte daqueles, que implique no dever de indenizar o prejuízo ocasionado.

O segundo pressuposto a ser examinado para o deferimento da cautela preparatória em questão é o risco de dano grave ou de difícil reparação - periculum in mora -, aqui há que se ater à possibilidade daquelas pessoas, em face das quais se busca a reparação, serem reduzidos à insolvabilidade (carência econômica), em virtude de se desfazerem de seu patrimônio por estarem no exercício do jus abutendi.

No que diz respeito a essa matéria merece transcrição os ensinamento do jurista Abrão ${ }^{5}$ a seguir:

Na medida em que a indisponibilidade patrimonial dos sócios ou antigos administradores resultar na efetividade do provimento, é salutar que se fundamente a determinação, a fim de que na condenação haja meio necessário ao pagamento do prejuízo imposto.

Singularmente, andou bem o legislador ao estabelecer o primado da compatibilidade entre a reserva e o valor exigido na demanda proposta contra os responsáveis. Assim, supõe-se um lineamento que possa respaldar o efeito de se alcançar um nexo causal entre ambos.

Perdurará a indisponibilidade até o sentenciamento do feito; porém, sendo acolhida a pretensão, evidente que a medida se manterá incólume, e na hipótese diversa quando for julgada improcedente, isso não exige necessariamente sua desconsideração, até em virtude da sujeição recursal no duplo efeito.

Realça-se o color da indenização como pressuposto da ação, daí por que a indisponibilidade visa prestigiar a regra da existência de bens que possam ser constritados no tempo adequado e que se mostrem compatíveis com os danos exigidos na lide.

O caráter acautelatório da media se reveste de substancial relevância por vários motivos: permite congelamento e subsunção do patrimônio, da informes suficientes à ação de responsabilização e, por derradeiro, evita eventuais fraudes com a transferência antes da propositura, facilitando assim $o$ ingresso de valores na massa falida.

De igual modo, trago a esse estudo jurisprudência do Tribunal de Justiça do Estado do Rio Grande do Sul, cujo voto condutor foi de minha lavra ${ }^{6}$, conforme se vê abaixo:

APELAÇÃO CÍVEL. FALÊNCIA. MEDIDA CAUTELAR DE SEQUESTRO. AÇÃO DE RESPONSABILIZAÇÃO DOS SÓCIOS DA FALIDA. RESTRIÇÃO JUDICIAL DE INDISPONIBILIDADE DOS BENS. POSSIBILIDADE JURÍDICA.

\section{Da preliminar de nulidade da sentença}

1. Não há que se falar em nulidade da sentença por desrespeito ao devido processo legal em função de que supostamente não teriam sido analisadas as provas dos autos, ou em função de ausência de fundamentação, quando atendido o ordenamento jurídico vigente, que adotou o princípio do livre convencimento motivado ou persuasão racional do Juiz.

2. Assim, todas as decisões judiciais devem ser assentadas em razões jurídicas, cuja invalidade decorre da falta destas, consoante estabelecem os artigos 93, inc.IX da Constituição Federal e 458 do Código de Processo Civil, o que inocorreu no presente feito, logo, rejeita-se a prefacial suscitada. 


\section{Mérito do recurso}

3. Denota-se dos autos que em abril de 2002 o Síndico da Massa Falida apelada ajuizou ação de responsabilidade contra os sócios da falida, em virtude dos desmandos apurados em relatório do Banco Central do Brasil, em perícia criminal e em processo crime, para tornar juridicamente possível a responsabilização pessoal e solidária destes pelas dívidas da sociedade.

4. Na presente ação cautelar de seqüestro foi determinada, liminarmente, a restrição judicial de indisponibilidade sobre os bens dos sócios da falida, a qual foi definitivamente confirmada na sentença de primeiro grau.

5. O Juiz pode determinar a restrição judicial de indisponibilidade sobre o bem imóvel da embargante com base no artigo 14, VI, do DecretoLei 7.661/45, aplicável ao caso em tela, a teor do que estabelece o art. 192 da Lei 11.101/2005.

6. Ressalte-se que a providência adotada encontra amparo atualmente no artigo 99, inciso VII, da novel Lei de Falências e Recuperação de Empresas, visto que se trata do poder geral de cautela, a fim de garantir a isonomia de tratamento entre os credores.

7. O Síndico tem o direito, em tese, de propugnar pela declaração de ineficácia dos atos praticados pelo falido que resultem na alienação de bens em flagrante prejuízo à massa, bem como, pleitear responsabilização direta dos sócios por eventual ilícito praticado por estes, cuja reparação repercuta em proveito da massa subjetiva.

Negado provimento ao apelo.

\section{b) Efeitos patrimoniais e vigência temporal}

O principal efeito sobre o patrimônio particular do sócio controlador, administrador ou conselheiro da companhia aberta é no que tange à faculdade de dispor do proprietário de determinada coisa afeta aquele, ainda que de forma parcial, isto é, restrita a transmissão do domínio ou a cessão dos direitos deste, a qual fica bloqueada provisória e temporariamente.

O efeito acessório patrimonial daí decorrente é a possibilidade jurídica de que, caso seja transferido o domínio de determinado bem, ou cedido os direitos sobre este, o referido ato ou negócio será ineficaz frente aos credores, caracterizando fraude à execução, por exemplo, na hipótese do executivo fiscal, caso aquela medida processual seja anterior essa relação jurídica e a esta execução.

Frise-se que a vigência temporal está adstrita à prescrição quinquenal da dívida ativa na hipótese da execução fiscal, bem como da decadência no lapso de dois (02) anos do direito de responsabilizar por eventual prejuízo ocasionado à empresa falida pelo sócio controlador, administrador e conselheiro, seja pertencente ao conselho administrativo ou fiscal da companhia aberta, na ação de responsabilização pessoal prevista na lei de falências, a contar do trânsito em julgado da decisão que decreta a quebra.

Ademais, a indisponibilidade de bens precitada poderá ser concedida com base no poder de cautela geral da lei processual civil, conforme disposto no art. 798, a fim de prevenir a ocorrência de lesão grave ou de difícil reparação, a qual pode se dar tanto de forma incidental quanto preparatória. Logo, havendo a possibilidade jurídica de responsabilização daqueles com base, por exemplo, na Lei especial das Sociedades Anônimas, cujo prazo de prescrição é o trienal, na forma do art. 287, inc. II, do referido diploma legal, o tempo de duração da medida poderá ser este, na hipótese de incidência em discussão.

Não obstante isso, a regra é que, a medida cautelar perdura até a fluência do prazo de exercício do direito da ação principal indicada para responsabilizar civilmente aqueles atores que têm atuação na companhia aberta, ou quando decaia aquele direito, em qualquer hipótese sempre haverá prazo certo de vigência da referida tutela jurisdicional vinculado ao tipo de pretensão a ser deduzida e a eficácia sentencial preponderante desta.

\subsection{Questões de ordem processual da indisponibilidade de bens}

No presente estudo é oportuno que se esclareça que a indisponibilidade de coisa, corpórea ou incorpórea, pertencente ao patrimônio do sócio controlador, administrador ou conselheiro, é uma medida cautelar assecuratória da reparação civil, mas não sujeita ao perdimento de pronto do referido bem, importando apenas em eventual ineficácia relativa à transmissão do domínio deste ou cessão dos direitos atinentes ao mesmo.

Por conseguinte, não é possível suprimir garantias constitucionais do exercício da ampla defesa (art. $5^{\circ}$, $\mathrm{LV}$, da CF), do direito ao devido processo legal (art. $5^{\circ}$, $\mathrm{LIV}$, da $\mathrm{CF}$ ), nem do direito à propriedade privada (art. $5^{\circ}$, XXII, da CF), cuja eventual perda desta decorre de regular provimento judicial e do reconhecimento da responsabilidade civil de reparar os prejuízos causados à companhia aberta, aos sócios desta ou a terceiro que mantenha relação jurídica com a referida empresa.

\section{a) Natureza jurídica e requisitos}

Trata-se aqui de matéria de ordem pública, pois processual, cuja natureza jurídica é de cunho cautelar preventiva, ou seja, a prestação jurisdicional não se exauriu com a eventual concessão provisória da tutela de indisponibilidade de bens, isto é, mediante o 
bloqueio da possibilidade jurídica de transmissão do domínio de determinada coisa, corpórea ou incorpórea, ou a cessão dos direitos desta.

É necessário que seja intentado o feito principal do qual a medida acautelatória precitada é acessória, a fim de que seja solvida a questão de direito material pertinente aquele, qual seja, o bom direito alegado na cautelar, assim como aferir o risco de ocorrer prejuízo grave (irreparável) ou de difícil reparação devido à demora da prestação jurisdicional.

Assim, os requisitos exigidos para apreciação da cautela preparatória de indisponibilidade de bens dos agentes antes mencionados, que atuam na companhia aberta, são: o fumus boni juris e o periculum in mora.

A primeira questão a ser analisada para concessão da tutela de indisponibilidade de bens é a existência de direito plausível, no sentido de que o sócio controlador, administrador ou conselheiro possam ter adotado conduta, comissiva ou omissiva, abusiva, contrária à lei ou ao estatuto da sociedade anônima de capital aberto, que resulte no dever de responder civilmente perante a sociedade, seus sócios ou terceiros com o patrimônio particular, em função do referido comportamento antijurídico.

Por fim, o último requisito a ser considerado para a concessão da cautela preventiva de indisponibilidade dos bens daqueles agentes é ocorrência de perigo efetivo de retardo na prestação jurisdicional, o qual importaria em prejuízo grave ou de difícil reparação, decorrente da insuficiência patrimonial resultante do exercício do direito de disposição dos bens particulares dos mesmos, cuja medida restritiva a ser adotada deve se limitar a exata proporção dos prejuízos que se pretende ressarcir na ação principal indicada.

\section{b) Consequências de ordem processual}

$\mathrm{O}$ primeiro corolário processual que decorre da medida de indisponibilidade dos bens é o de que descabe este tipo de cautela se não há plausibilidade do direito alegado como bom, nem existe o risco de ocorrer dano grave ou de difícil reparação, pois se há patrimônio suficiente e a alienação de determinado bem não desfalca este, a ponto de reduzir o devedor à insolvabilidade, carece o pleito de causa jurídica para conceder aquela.

Outra consequência que exsurge da cautela de indisponibilidade de bens em exame, é que ela importa em mera restrição parcial da faculdade de disposição atinente ao direito de propriedade, provisória e temporária, cuja deliberação final a esse respeito se dará apenas quando houver a decisão no feito principal do qual a mesma serve apenas para garantir e efetividade desta.
Ainda, há que se aplicar a esse tipo de cautela preparatória o princípio da proporcionalidade, isto é, atenta-se aqui a limitação do estado-juiz, detentor do poder público, no sentido de que a restrição do direito de propriedade precitada não importe em ônus maior do que o objetivo perseguido, qual seja de garantir patrimônio suficiente para eventual reparação de prejuízo causado.

Aliás, a esse respeito à doutrinadora Taíza Ribeiro ${ }^{7}$ tece os comentários pertinentes quanto ao tema discutido abaixo:

Os princípios da proporcionalidade e razoabilidade, nas palavras de Fabrício dos Reis Brandão contém elementos intrínsecos para sua utilização na solução dos conflitos, que se dividem em subprincípios, quais sejam: adequação, exigibilidade e proporcionalidade em sentido estrito". Nesse liame, extrai-se que a proporcionalidade subdividese em três aspectos: a adequação, a necessidade e a proporcionalidade estritamente. A adequação referese à escolha de uma medida coerente e propícia a alcançar o fim almejado. Por sua vez, a necessidade diz respeito à escolha do meio estritamente necessário e imprescindível para a consecução do fim objetivado, sem exceder os limites indispensáveis. E, por fim, a proporcionalidade em sentido estrito significa que o ônus, o sacrifício gerado ao valor sacrificado deve ser menor do que as vantagens advindas do valor preponderante.

Desse modo, a cautela preventiva em questão não pode desbordar da extensão do prejuízo que se pretende reparar, devendo guardar relação e proporcionalidade a este, de sorte que a medida imposta assegure o direito vindicado, sem importar em ônus desmedido ao proprietário da coisa sujeita a esta restrição que ultrapasse o objetivo a ser alcançado na demanda principal.

\section{CONCLUSÃO}

A natureza jurídica da tutela de indisponibilidade de bens é de cautelar preventiva, que visa garantir a solvência patrimonial para hipótese de ser responsabilizado pessoalmente o sócio controlador, administrador ou conselheiro, seja fiscal ou administrativo, pela prática de conduta lesiva à sociedade anônima aberta, em decorrência do poder de gestão, administração ou de fiscalização sobre os atos e negócios jurídicos desta.

É oportuno destacar que para surtirem efeitos sobre os bens particulares dos sócios controladores, administradores e conselheiros, como analisado anteriormente, a eficácia pretendida e a medida preparatória decorrem de justa causa e estão, necessariamente, 
vinculadas a ato ou a negócio jurídico certo, que se mostraram danosos aos interesses da companhia aberta, demais sócios ou a terceiro. Aliado ao fato de que a tutela em questão possui caráter excepcional, pois o bom direito alegado na cautela proposta deve estabelecer o nexo causal entre a conduta antijurídica praticada e o resultado descrito, isto é, o prejuízo econômico determinado ou determinável.

Assim, a referida medida cautelar vigora por prazo certo, ou seja, até a apuração da responsabilidade daqueles que respondem com o patrimônio particular pelo prejuízo ocasionado à sociedade anônima de capital aberto, aos sócios destas e mesmo a terceiros, que mantêm relação jurídica com a referida companhia.

Trata-se a indisponibilidade de bens de cautela provisória de restrição de uma das faculdades do domínio, no caso, o direito de dispor livremente daquele patrimônio, até que seja apurada a responsabilidade dos atores precitados pelos prejuízos que deram causa.

A primeira questão a ser analisada para concessão da tutela de indisponibilidade de bens é a existência de direito plausível - fumus boni juris -, no sentido de que o sócio controlador, administrador ou conselheiro possam ter adotado conduta, comissiva ou omissiva, abusiva, contrária à lei ou ao estatuto da sociedade anônima de capital aberto, que resulte no dever de responder civilmente perante a sociedade, seus sócios ou terceiros com o patrimônio particular, em função do referido comportamento antijurídico.
O último requisito a ser considerado para a concessão da cautela preventiva de indisponibilidade dos bens daqueles agentes é ocorrência de perigo efetivo de retardo na prestação jurisdicional - periculum in mora -, o qual importaria em prejuízo grave ou de difícil reparação, decorrente da insuficiência patrimonial resultante do exercício do direito de disposição dos bens particulares dos mesmos, cuja medida restritiva a ser adotada deve se limitar a exata proporção dos prejuízos que se pretende ressarcir na ação principal indicada.

\section{REFERÊNCIAS}

ABRÃO. Carlos Henrique. In: TOLEDO, Paulo F. C. Salles; ABRÃO, Carlos Henrique (coord.). Comentários à lei de recuperação de empresas e falência. 3. ed. São Paulo: Saraiva, 2009. p. 251-252.

CARVAlHOSA, Modesto, Comentários à Lei de Sociedades Anônimas. São Paulo: Saraiva, 1997. Vol. 1: arts. 1ª 74, p. 31-32.

COMPARATO, Fábio Konder, O poder de controle na sociedade anônima. 3. ed. Rio de Janeiro: Forense, 1983. p. 107.

RIBEIRO, Taíza Irene de Haro Pouchain. A indisponibilidade dos bens na cautelar fiscal e sua extensão ao ativo circulante. Revista da PGFN, p. 161-184.

THEODORO JÚNIOR, Humberto, medida cautelar fiscal responsabilidade tributária do sócio-gerente (CTN, art. 135). Revista dos Tribunais, São Paulo v. 739 p. 115, maio 1997. Doutrinas essenciais de Direito Tributário, v. 6, p. 453, fev. 2011. STJ, PRIMEIRA TURMA, REsp 722.998/MT, Rel. Ministro LUIZ FUX, julgado em 11/04/2006, DJ 28/04/2006, p. 272.

TJRS, 5a Câmara Cível, processo nº 70036298545 , julgado em 26.01.2011.

\section{NOTAS}

1 CARVAlHOSA, Modesto. Comentários à Lei de Sociedades Anônimas. São Paulo: Saraiva, 1997, v. 1: arts. 1º a 74, p. 31-32.

2 COMPARATO, Fábio Konder, $O$ poder de controle na sociedade anônima, 3. ed. Rio de Janeiro: Forense, 1983, p. 107.

3 THEODORO JÚNIOR, Humberto, medida cautelar fiscal - responsabilidade tributária do sócio-gerente (CTN, art. 135). Revista dos Tribunais, São Paulo, v. 739, p. 115, maio 1997. Doutrinas Essenciais de Direito Tributário, v. 6, p. 453, fev. 2011.
4 STJ, PRIMEIRA TURMA, REsp 722.998/MT, Rel. Ministro LUIZ FUX, julgado em 11/04/2006, DJ 28/04/2006, p. 272.

5 ABRÃO. Carlos Henrique. In: TOLEDO, Paulo F. C. Salles; ABRÃO, Carlos Henrique (coord.). Comentários à lei de recuperação de empresas e falência. 3. ed. São Paulo: Saraiva, 2009, p. 251-252.

6 TJRS, 5a Câmara Cível, processo no 70036298545 , julgado em 26.01.2011.

7 RIBEIRO, Taíza Irene de Haro Pouchain, A indisponibilidade dos bens na cautelar fiscal e sua extensão ao ativo circulante. Revista da PGFN, p. 161-184. 